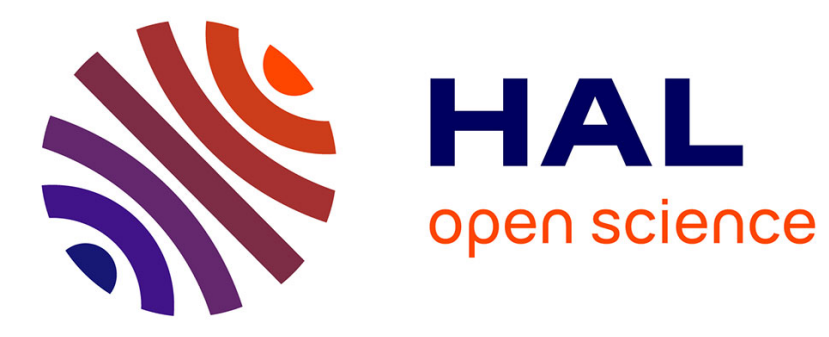

\title{
Intra-family distribution of paid-work time
}

Jose Alberto Molina, Inmaculada Garcia, Victor Manuel Montuenga

\section{To cite this version:}

Jose Alberto Molina, Inmaculada Garcia, Victor Manuel Montuenga. Intra-family distribution of paid-work time. Applied Economics, 2010, 42 (05), pp.589-601. 10.1080/00036840701704469 . hal00582200

\section{HAL Id: hal-00582200 \\ https://hal.science/hal-00582200}

Submitted on 1 Apr 2011

HAL is a multi-disciplinary open access archive for the deposit and dissemination of scientific research documents, whether they are published or not. The documents may come from teaching and research institutions in France or abroad, or from public or private research centers.
L'archive ouverte pluridisciplinaire HAL, est destinée au dépôt et à la diffusion de documents scientifiques de niveau recherche, publiés ou non, émanant des établissements d'enseignement et de recherche français ou étrangers, des laboratoires publics ou privés. 


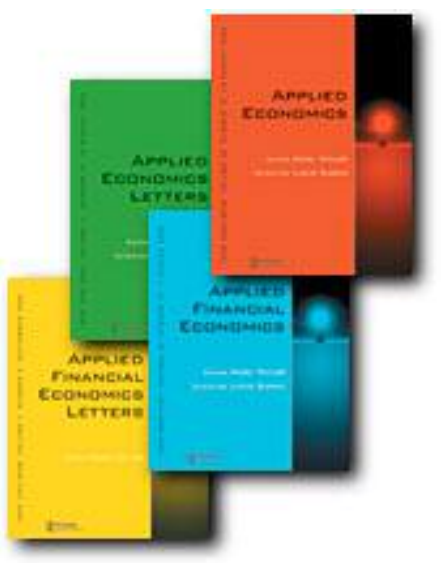

Intra-family distribution of paid-work time

\begin{tabular}{|c|c|}
\hline Journal: & Applied Economics \\
\hline Manuscript ID: & APE-06-0750.R1 \\
\hline Journal Selection: & Applied Economics \\
\hline $\begin{array}{r}\text { Date Submitted by the } \\
\text { Author: }\end{array}$ & 19-Sep-2007 \\
\hline Complete List of Authors: & $\begin{array}{l}\text { Molina, Jose Alberto; University of Zaragoza and IZA } \\
\text { Garcia, Inmaculada; University of Zaragoza } \\
\text { Montuenga, Victor Manuel; University of La Rioja }\end{array}$ \\
\hline JEL Code: & $\begin{array}{l}\text { D13 - Household Production and Intrahousehold Allocation \&lt; D1 - } \\
\text { Household Behavior and Family Economics \&lt; D - Microeconomics, } \\
\text { J22 - Time Allocation and Labor Supply \&lt; J2 - Time Allocation, } \\
\text { Work Behavior, and Employment Determination/Creation \&lt; J - } \\
\text { Labor and Demographic Economics }\end{array}$ \\
\hline Keywords: & Intra-family, Paid-work time, Collective model \\
\hline
\end{tabular}

\section{\scholarONE" \\ Manuscript Central}




\title{
Intra-family distribution of paid-work time
}

\author{
INMACULADA GARCIA ${ }^{\mathrm{a}}$, JOSÉ ALBERTO MOLINA ${ }^{\mathrm{b}}$ and \\ VICTOR MANUEL MONTUENGA ${ }^{\mathrm{c}}$ \\ ${ }^{a}$ Department of Economic Analysis, University of Zaragoza, Zaragoza, Spain \\ ${ }^{\mathrm{b}}$ Department of Economic Analysis, University of Zaragoza, Zaragoza, Spain, and Institute \\ for the Study of Labor-IZA, Bonn, Germany \\ ${ }^{\mathrm{c}}$ Department of Economics and Business, University of La Rioja, Logroño, Spain
}

\begin{abstract}
This paper analyses the intra-family distribution of paid-work time in five European countries (France, Germany, Italy, Spain and the UK). To that end, we formulate a collective model which allows us to characterise the efficient labour supply decisions of each spouse. This two-equation model is then simultaneously estimated by using national panel data drawn from the European Community Household Panel-ECHP (1994-2001). Empirical results clearly show that, in all sample countries, the labour supply of wives is affected by own wages, household and own non-labour incomes and the number of children, whereas evidence for husbands differs across countries.
\end{abstract}

Keywords: Intra-family; Paid-work time; Collective model.

Correspondence: José Alberto Molina. Department of Economic Analysis. Faculty of Economics. University of Zaragoza. Gran Vía, 2. 50005. Zaragoza. Spain. Tel: 976761818. Fax:976 761996. E-mail: jamolina@unizar.es 


\section{INTRODUCTION}

In recent times, we have witnessed an increasing amount of research effort devoted to pursuing an adequate theoretical framework for modelling the process of intra-family decision-making. A review of the literature appears to confirm that the traditional or unitary approach, which assumes that a household, even if it consists of different individuals, acts as a single decision-making unit, is giving way to an alternative view, which considers that a household can be seen as a micro-society consisting of several individuals with their own rational preferences. ${ }^{1}$

This evolution is due to the fact that the unitary approach suffers from a number of both methodological and empirical weaknesses. Thus, from the methodological perspective, the idea that subjective preferences are inseparable from individual behaviour leads to an alternative approach, which explicitly takes into account the notion that a household is a group of individuals, with different preferences, and among whom an intra-family decisionmaking process takes place. As regards empirical weaknesses, the most relevant appears in the context of the welfare analysis, since the unitary model leaves no room to determine the intra-family distribution of consumption or time and, consequently, of welfare. ${ }^{2}$ As a result, knowledge of the intra-family decision process may be important for the design of policy programs whose aim is to contribute to the development of family members and, in this way, of the household as a whole.

In response to these weaknesses, two fruitful approaches have emerged in the literature which explicitly take into account several decision-makers in a household by

\footnotetext{
${ }^{1}$ Samuelson (1956) and Becker (1974a, 1974b) represent the early attempts to account for the fact that households may consist of different individuals with their own preferences. However, in both cases the authors finally accepted the traditional approach: in the first case, through an aggregate utility function which is achieved by consensus among the individuals; in the second, by assuming the utility function of a benevolent head of the family, who takes into account the preferences of all household members.

${ }^{2}$ Other empirical restrictions, strongly rejected in the literature, include the income pooling hypothesis and the symmetry of the Slutsky matrix (see, among others, Kooreman and Kapteyn, 1987; Schultz, 1990; Thomas, 1990; Fortin and Lacroix, 1997; Tiefenthaler, 1999). With respect to the former, this implies that individual non-labour incomes of the household members are pooled in a single household non-labour income which, in turn, implies that the source of this exogenous income plays no role in the household's distribution. As regards the latter, this requires that marginal compensated price changes of two individuals in a household have the
} 
using game theory elements. The first of these models household behaviour in a noncooperative framework, in such a way that the Nash equilibrium implies that family members are assumed to maximise their utility, taking the other individuals' behaviour as given (see, for example, Weiss and Willis, 1985; Kooreman and Kapteyn, 1990; Konrad and Lommerud, 1995; Browning, 2000). The second incorporates elements of co-operative game theory in a household model, specifically that of axiomatic bargaining theory, in such a way that household members reach the Nash or the Kalai-Smorodinsky solutions after trying to come to an agreement on how to divide the gains of co-operation (see Manser and Brown, 1980; McElroy and Horney, 1981, McElroy, 1990). Despite the clear relevance of these two game theory approaches, one important drawback they share is that if the empirical implications of such approaches are rejected, then it is impossible to determine whether the choice of a particular bargaining concept itself, or the bargaining approach in general, is the cause of such rejection.

Against this background, Chiappori $(1988,1992,1997)$ adopts, within the cooperative view, an alternative, and gradually more accepted approach, namely the collective model, which is based on the assumption that intra-family decisions are Pareto-efficient, thus making it possible to derive some testable implications and to identify an important part of the intra-family decision-making process. Several reasons justify the adequacy of this approach. First, it is reasonable to assume that the result of a repeated game under perfect information on each other's preferences within a household is Pareto-efficient; secondly, this is the most natural generalisation of the utility maximisation in the unitary model with several household members; and, thirdly, most of the commonly applied bargaining rules usually assume this view. The collective approach considers that preferences depend on wages, prices and individual non-labour incomes, in such a way that the distribution of the bargaining power within a household may depend on the level of each of these variables. Moreover, this alternative approach overcomes the two fundamental empirical restrictions of the unitary model, that is to say, the income pooling hypothesis and the symmetry of the Slutsky matrix, and can be also seen as a more general model which encompasses the unitary model.

same effect on each other's goods demands. 
Bearing in mind that the collective model allows us to test for such a setting through testable implications derived from it and then to estimate the structural model from observed behaviour, the aim of this paper is, first, to test the adequacy of the collective approach in five representative EU countries (France, Germany, Italy, Spain and the UK) and, in the positive case, to analyse the intra-family distribution of paid-work time by estimating labour supply functions.

After transforming the two-equation paid-work time model into its empirical counterpart, we simultaneously estimate this specification by using national panel data drawn from the European Community Household Panel-ECHP (1994-2001). The structure of the panel, which includes relevant information on the factors that affect the alternative uses of household time, specifically those related to working outside the home in a paid job, allows us to control the unobservable heterogeneity problem, as well as to eliminate the bias derived from aggregation.

In order to fulfil the identification and testability requirements of the collective approach, we follow Chiappori et al. (2002) in considering the existence of distribution factors. These are variables that may have an influence on family behaviour through their effect on the intrahousehold decision process, but which do not affect either individual preferences or the household budget constraint. Some examples used in the literature are the sex ratio, divorce laws, differences in incomes, in ages or in education levels between both spouses. As discussed below, in our particular case, we use the share of the wife's nonlabour income over the household non-labour income.

Our paper sets out to make three main contributions. First, we present evidence about the collective model of household labour supplies for a set of countries using the same database, thereby allowing us to make a comparative analysis of the intra-family distribution of paid-work time in European economies. The second contribution is the use of techniques related to panel data with the aim of controlling for unobserved heterogeneity. At the same time, endogeneity arising from simultaneity is also considered in the estimation process. Finally, the value of the estimations based on this collective framework lies in obtaining evidence about the family characteristics that influence decisions on the hours 
dedicated to such paid-work, and how these hours are shared out among the family.

The rest of the paper is organised as follows. Section II presents the theoretical framework and the empirical specification. The data and the estimation procedure are described in Section III. The results and policy implications are discussed in Section IV. Finally, Section V closes the paper with a summary of the most relevant conclusions.

\section{THEORETICAL FRAMEWORK}

\section{II.1. The collective model}

The traditional approach of a unitary model, which assumes that a family acts as a single decision-making unit, has given way in the literature to an alternative view which considers that a household can be seen as a micro-society consisting of several individuals with their own rational preferences. Within this framework, Chiappori and his co-authors (Chiappori, 1988, 1992; Browning et al., 1994; Browning and Chiappori, 1998; Chiappori et al., 2002) propose an approach that has gradually gained more acceptance in both theoretical and empirical applied work. ${ }^{3}$ The so-called collective model, which is based on the assumption that intra-household decisions are Pareto-efficient, considers that the household consists of two working-age persons, $A=$ husband and $B=$ wife, whose rational preferences can be represented by individual utility functions that, in general, are assumed to be altruistic, in such a way that each of them is defined on their own vectors of goods and time, as well as on the other member's vectors:

$$
u^{i}=u^{i}\left(q^{A}, q^{B}, q_{0}^{A}, q_{0}^{B}, z\right)
$$

where $u^{i}, \quad i=A, B$, are strongly quasi-concave, increasing and twice continuously differentiable functions. The arguments are the consumption of each of the spouses, $q^{A}$ and

\footnotetext{
${ }^{3}$ See Vermeulen (2002) for an excellent recent survey on the collective household approach.
} 
$q^{B}$, whose prices are unity, as well as their leisure times $q_{0}^{A}$ and $q_{0}^{B},{ }^{4}$ with $z$ being a vector of preference variables including family characteristics. Furthermore, the household budget restriction is:

$$
q^{A}+q^{B}+\omega^{A} q_{0}^{A}+\omega^{B} q_{0}^{B} \leq y+\left(\omega^{A}+\omega^{B}\right) T
$$

where $\omega^{i}$ denotes the individual wages, $y$ is the family non-labour income and, finally, $T$ is the time endowment.

According to the collective approach, the household demand functions can be derived from an intra-family decision process whose only requirement is that it must lead to Paretoefficient allocations, with such a process being formally implemented in the following maximisation problem:

$$
\begin{aligned}
& \underset{q^{A}, q^{B}, q_{0}^{A}, q_{0}^{B}}{\operatorname{Max}} u^{A}\left(q^{A}, q^{B}, q_{0}^{A}, q_{0}^{B}, z\right) \\
& \text { s. to } u^{B}\left(q^{A}, q^{B}, q_{0}^{A}, q_{0}^{B}, z\right) \geq \bar{u}^{B} \\
& q^{A}+q^{B}+\omega^{A} q_{0}^{A}+\omega^{B} q_{0}^{B} \leq y+\left(\omega^{A}+\omega^{B}\right) T
\end{aligned}
$$

where $\bar{u}^{B}$ is some required utility level for individual $B$. From this initial problem, $\bar{u}^{B}$ can be modified in order to obtain all the Pareto-efficient allocations, with these forming the boundary of the utility possibility set.

Given the initial assumption that the individual utility functions are strictly quasiconcave, and that the budget restriction defines a convex set, the utility possibilities set will be strictly convex. Consequently, all the Pareto-efficient allocations can be characterised as points of a linear social welfare function with positive weights for both household members in the joint welfare. Thus, the above problem can be expressed in the following terms:

\footnotetext{
${ }^{4}$ Habitually, only the total household consumption is observed (and not the individual consumptions). We then talk of the Hicksian aggregate commodity.
} 


$$
\begin{aligned}
& \underset{q^{A}, q^{B}, q_{0}^{A}, q_{0}^{B}}{\operatorname{ax}} \mu\left(\omega^{A}, \omega^{B}, y, \boldsymbol{s}, z\right) u^{A}\left(q^{A}, q^{B}, q_{0}^{A}, q_{0}^{B}, z\right)+\left[1-\mu\left(\omega^{A}, \omega^{B}, y, \boldsymbol{s}, z\right)\right] u^{B}\left(q^{A}, q^{B}, q_{0}^{A}, q_{0}^{B}, z\right) \\
& \text { s. to } q^{A}+q^{B}+\omega^{A} q_{0}^{A}+\omega^{B} q_{0}^{B} \leq y+\left(\omega^{A}+\omega^{B}\right) T
\end{aligned}
$$

where $\mathbf{s}$ is a vector of distribution factors. In this optimisation problem, the weights $\mu\left(\omega^{A}, \omega^{B}, y, \boldsymbol{s}, z\right)$ and $\left[1-\mu\left(\omega^{A}, \omega^{B}, y, \boldsymbol{s}, z\right)\right]$ are the (normalised) Lagrangian multipliers of problem (3), with these being interpreted as indicators of the bargaining power of the household members in the intra-family distribution process. ${ }^{5}$ They are assumed to be continuously differentiable and homogeneous of degree zero in $y$ and $\boldsymbol{w}$. As can be appreciated from these expressions, the collective setting implies that the bargaining power depends on the individual wages, $\left(\omega^{A}, \omega^{B}\right)$, the household non-labour income, $y$, the set of family characteristics, $z$, and the distribution factor, $s$. These latter distribution factors denote variables that have an influence on family behaviour through their effect on the intrahousehold decision process (i. e. on the bargaining power function $\mu$ ), but that do not affect either an individual's preferences or the household budget constraint (Browning et al. 1994; Browning and Chiappori, 1998).

The main limitation of this general setting derives from the fact that the structural model is not uniquely identified with altruistic preferences, in such a way that additional assumptions are required in order to identify the structural model. Note, however, that the integrability requirements do hold under both egoistic and caring à la Becker preferences (Chiappori, 1988, 1992). As a consequence, in what follows, we will consider the first of these in order to simplify the notation, although the results are easily extended to the case of the most general Beckerian utility functions.

Thus, assuming that family members only care about their own decision variables, $u^{i}=u^{i}\left(q^{i}, q_{0}^{i}, z\right)$, the second fundamental theorem of welfare shows that the efficient solution derived from this optimization problem is equivalent to a two-stage decision

\footnotetext{
${ }^{5}$ According to this view, the household optimum allocation can vary as a consequence of a change in the nonlabour income both, directly, via the usual income effect, and indirectly through a shift in the bargaining
} 
process (Chiappori, 1992). In the first stage, both family members share the household nonlabour income according to an exogenous and unobservable sharing rule which characterises the bargaining process within the household:

$$
\begin{aligned}
& \phi^{A}=\phi\left(\omega^{A}, \omega^{B}, y, \boldsymbol{s}, z\right) \\
& \phi^{B}=y^{A}+y^{B}-\phi\left(\omega^{A}, \omega^{B}, y, \boldsymbol{s}, z\right)
\end{aligned}
$$

where $\phi^{i}$ represents the fraction of the household non-labour income that each member receives. The share depends on the bargaining power of the household members which, in turn, depends on wages, total non-labour income, sociodemographic variables and distribution factors. It is assumed to be twice continuously differentiable. Once the total non-labour income has been allocated between the individuals, in the second stage each family member maximises his/her own utility function, subject to his/her own budget restriction:

$$
\begin{array}{ll}
\operatorname{Max}_{q^{i}, q_{0}^{i}} & u^{i}=u^{i}\left(q^{i}, q_{0}^{i}, z\right) \\
\text { s.to } & q^{i}+\omega^{i} q_{0}^{i} \leq \phi^{i}+\omega^{i} T
\end{array}
$$

Assuming an interior solution and provided that individual preferences are assumed to be weakly separable in $\left(q^{i}, q_{0}^{i}\right)$, the individual labour supply functions of each spouse can be written as:

$$
\begin{aligned}
& h^{A}\left(\omega^{A}, \omega^{B}, y, \boldsymbol{s}, z\right)=H^{A}\left(\omega^{A}, \phi^{A}\left(\omega^{A}, \omega^{B}, y, \boldsymbol{s}, \boldsymbol{z}\right)\right) \\
& h^{B}\left(\omega^{A}, \omega^{B}, y, \boldsymbol{s}, z\right)=H^{B}\left(\omega^{A}, y-\phi\left(\omega^{A}, \omega^{B}, y, \boldsymbol{s}, \boldsymbol{z}\right)\right)
\end{aligned}
$$

power. This means that the income pooling hypothesis no longer needs to be true. 
where $H^{i}$ are the Marshallian labour supply functions corresponding to the second stage of the problem and, therefore, are conditional on the sharing rule. ${ }^{6}$

In this framework, Chiappori et al. (2002) show that it is possible to derive testable restrictions on observed individuals' labour supply behaviour, and to recover the sharing rule function up to an additive constant. Despite that, even without distribution factors, Chiappori $(1988,1992)$ demonstrated that, under egoistic or caring preferences, the model is identified and the testable requirements are satisfied. The inclusion of distribution factors provides a simpler and more robust method of identification and the derivation of testable restrictions relies on first and second-order partial derivatives of the individuals' labour supplies. Several distribution factors have been used in applied work, with differences in income between spouses having been the benchmark (Browning et al., 1994). More recently, Chiappori et al. (2002) used the state sex ratio and the divorce legislation; Clark et al. (2002), in addition to the regional sex ratio, employed other factors, such as the parents' occupational level or variables measuring political and sociological involvement; Crespo (2005) used, among others, the differences in education level between spouses. Given that only one distribution factor is needed for the testability and integrability requirements (Chiappori et al., 2002), in this work we consider that the intrahousehold decision process may be affected by the amount of non-labour income that each spouse pools to the household income. Specifically, the distribution factor we use is the fraction of the wife's non-labour income over the household non-labour income, with this variable influencing both members' labour supply behaviour through the sharing rule, but without affecting either individual preferences or the household budget constraint.

\section{II.2. Parametric specification}

In order to derive the testable restrictions, assumptions about the functional form of either the utility function or the labour supply functions must be imposed. Different empirical

\footnotetext{
${ }^{6}$ Empirical evidence on household labour supply for a number of countries has been found in, for example, Kawaguchi, 1994; Pradhan and Van Soest, 1997; Seaton, 1997; García and Molina, 1998; Barmby and Smith, 2001; Flood et al., 2004; Doiron and Guyonne, 2005; and Iyigun and Walsh, 2007. Additionally, particular studies on full-time/part-time work of spouses are, for example, Yamada and Yamada, 1987; Powel, 1998; and Connelly and Kimmel, 2003.
} 
specifications have been used in applied work (see Fortin and Lacroix, 1997; Chiappori et al., 2002; Fernández-Val, 2003; Bloemen, 2004). From among those used in this literature, we have chosen both semilog and quadratic parametric representations that allow us to test the restrictions imposed by the collective framework on the observed labour supplies. These particular functional forms for the unrestricted labour supply system satisfy two widely followed criteria, namely flexibility in response to wage changes, and the possibility of recovering the sharing rule.

The semilog specification is fully described in Chiappori et al. (2002), with its main advantage being that the log form for the wages is more realistic than the habitually applied "pure" linear form:

$$
\begin{aligned}
& h^{\mathrm{A}}=\alpha_{0}+\alpha_{1} \log \omega^{A}+\alpha_{2} \log \omega^{B}+\alpha_{3} \log \omega^{A} \log \omega^{B}+\alpha_{4} y+\alpha_{5} s+\alpha_{6} z \\
& h^{B}=\beta_{0}+\beta_{1} \log \omega^{A}+\beta_{2} \log \omega^{B}+\beta_{3} \log \omega^{A} \log \omega^{B}+\beta_{4} y+\beta_{5} s+\beta_{6} z
\end{aligned}
$$

The application of the general conditions derived in Chiappori et al. (2002) to these two unrestricted parametric models allows us to determine that there is only one parametric restriction: $\frac{\alpha_{3}}{\beta_{3}}=\frac{\alpha_{5}}{\beta_{5}}{ }^{7}$ If this restriction is empirically satisfied, we can obtain a characterisation of the intrahousehold allocation process in terms of the following expression for the sharing rule:

$$
\begin{aligned}
& \phi\left(\omega^{A}, \omega^{B}, y, \boldsymbol{s}, \boldsymbol{z}\right)= \\
& =\frac{1}{\Delta}\left(\alpha_{3} \beta_{1} \log \omega^{A}+\alpha_{2} \beta_{3} \log \omega^{B}+\alpha_{3} \beta_{3} \log \omega^{A} \log \omega^{B}+\alpha_{4} \beta_{3} y+\alpha_{5} \beta_{5} \boldsymbol{s}+\alpha_{6} \beta_{6} z\right)+k
\end{aligned}
$$

where $\Delta=\left(\alpha_{4} \beta_{3}-\alpha_{3} \beta_{4}\right)$ and $k$ is a parameter that cannot be identified without additional assumptions (see Chiappori et al., 2002).

\footnotetext{
${ }^{7}$ Whenever $\alpha_{4} / \beta_{4}$ is different from $\alpha_{5} / \beta_{5}$
} 
In order to be general enough to capture different behaviour across countries, we also use a quadratic specification. This offers several other advantages, in that, in addition to being linear in parameters, it provides a greater degree of flexibility since it includes the quadratic terms in wages, thereby allowing for backward bending labour supply. It operates in the following way:

$$
\begin{aligned}
& h^{\mathrm{A}}=\gamma_{0}+\gamma_{1} \omega^{A 2}+\gamma_{2} \omega^{B 2}+\gamma_{3} \omega^{A} \omega^{B}+\gamma_{4} \omega^{A}+\gamma_{5} \omega^{B}+\gamma_{6} y+\gamma_{7} \boldsymbol{s}+\gamma_{8} z \\
& h^{B}=\delta_{0}+\delta_{1} \omega^{A 2}+\delta_{2} \omega^{B 2}+\delta_{3} \omega^{A} \omega^{B}+\delta_{4} \omega^{A}+\delta_{5} \omega^{B}+\delta_{6} y+\delta_{7} \boldsymbol{s}+\delta_{8} z
\end{aligned}
$$

The application of the same general conditions as above allows us to determine that, once again, there is only one parametric restriction: $\frac{\gamma_{3}}{\delta_{3}}=\frac{\gamma_{7}}{\delta_{7}}$. As was earlier the case, if this restriction is empirically satisfied, we can obtain the following expression for the sharing rule:

$$
\begin{aligned}
& \phi\left(\omega^{A}, \omega^{B}, y, \boldsymbol{s}, \boldsymbol{z}\right)= \\
& =\frac{1}{\Delta}\left(\alpha_{3} \beta_{1} \omega^{A 2}+\alpha_{2} \beta_{3} \omega^{B 2}+\alpha_{3} \beta_{3} \omega^{A} \omega^{B}+\alpha_{3} \beta_{4} \omega^{A}+\alpha_{5} \beta_{3} \omega^{B}+\alpha_{6} \beta_{3} y+\alpha_{7} \beta_{3} s\right)+k
\end{aligned}
$$

where $\Delta=\left(\alpha_{6} \beta_{3}-\alpha_{3} \beta_{6}\right)$ and $\mathrm{k}$ is a parameter that cannot be identified without additional assumptions.

\section{EMPIRICAL MODEL AND DATA}

\section{III.1. Empirical model}

In order to develop the empirical specification, a number of considerations should be made. First, given that the ECHP data base does not include information with respect to the time spent on housework, we have had to include this in our leisure time, an activity not considered in our analysis. 
Secondly, the panel data structure allows us to apply techniques that help to control for unobservable heterogeneity. In this respect, there are three potential sources of unobservable heterogeneity: the sharing rule and the two individual preferences. The most satisfactory treatment would be to allow for each of them and then to develop a full stochastic model that would also allow us to take account of the possible endogeneity of the sample selection of married couples in full-time employment (Browning et al., 1994). However, following these authors and Blundell et al. (2002) we adopt a much more conventional approach of simply adding error terms to each labour supply equation, allowing for individual effects to control for unobservable heterogeneity but ignoring the possible sample selection bias. ${ }^{8}$

Thirdly, the distribution factor, s, considered in this analysis is given by a variable that reflects the share over the household non-labour income that corresponds to the wife, while vector $z$ gathers a series of a priori exogenous variables that influence individuals' decisions. ${ }^{9}$ The rationale for the distribution factor is that a higher share allocated by the wife indicates a higher relative power in the decision-making process. This will imply, conditioned on the wage rate, a lower number of hours of work for the wife as a result of a standard income effect, under the assumption that leisure is a normal good. The influence of this factor on the husband's labour supply function will have the opposite sign, according to the same argument.

In line with the above, the empirical labour supply functions we estimate take the following semilog or quadratic forms:

\footnotetext{
${ }^{8}$ This supposes we are not considering the possibility of nonparticipation in the labour market and then selectivity bias may arise. Rather, we focus on the case of the interior solutions. The main reasons why we have opted to ignore this bias in our analysis are the difficulties in both considering corner solutions in the collective model (see Blundell et al., 2002; Donni, 2003; and Bloemen, 2004) and, similarly, dealing with selectivity bias in the case of panel data estimation (see Wooldridge, 2002, Kyriazidou, 1997). The consideration of all these possibilities is beyond the scope of this paper and is left for future research.

${ }^{9}$ As stated earlier, different distribution factors have been used in applied work. Although we have tried a number of these, we finally chose this one given the inadequacy or non-significance of other possibilities. Thus, divorce laws are common within a country, the low regional disaggregation in the database used makes the construction of appropriate sex ratios more difficult, while differences in ages, in educational levels or in experiences between spouse are not applicable with the fixed effects estimation, which was ultimately selected, since they are time-invariant. Finally, this is a potentially continuous function and, thus, does not give rise to any incompatibility with the required assumption of continuously differentiability of the sharing rule, which usually fails elsewhere (Chiappori et al., 2002; Clark et al., 2002; Crespo, 2005).
} 


$$
\begin{aligned}
& h^{\mathrm{A}}=\alpha_{0}+\alpha_{1} \log \omega^{A}+\alpha_{2} \log \omega^{B}+\alpha_{3} \log \omega^{A} \log \omega^{B}+\alpha_{4} y+\alpha_{5} s+\alpha_{6} z+\varepsilon^{A} \\
& h^{B}=\beta_{0}+\beta_{1} \log \omega^{A}+\beta_{2} \log \omega^{B}+\beta_{3} \log \omega^{A} \log \omega^{B}+\beta_{4} y+\beta_{5} s+\beta_{6} z+\varepsilon^{A} \\
& h^{\mathrm{A}}=\gamma_{0}+\gamma_{1} \omega^{A 2}+\gamma_{2} \omega^{B 2}+\gamma_{3} \omega^{A} \omega^{B}+\gamma_{4} \omega^{A}+\gamma_{5} \omega^{B}+\gamma_{6} y+\gamma_{7} s+\gamma_{8} z+\varepsilon^{A} \\
& h^{B}=\delta_{0}+\delta_{1} \omega^{A 2}+\delta_{2} \omega^{B 2}+\delta_{3} \omega^{A} \omega^{B}+\delta_{4} \omega^{A}+\delta_{5} \omega^{B}+\delta_{6} y+\delta_{7} s+\delta_{8} z+\varepsilon^{B}
\end{aligned}
$$

where $\varepsilon=\left(\varepsilon^{A}, \varepsilon^{B}\right)$ is the vector of error terms that include individuals' unobservables, possibly correlated within the household, but not across households

At this point, it should be mentioned that there are some econometric concerns that must be properly dealt with. The ECHP provides annual earnings and weekly hours worked, so that hourly wage rates are computed by dividing annual earnings coming from paid-work by the number of hours worked in a week times the number of weeks in a year. This computation may generate some measurement error in the wage variable. This fact, and the simultaneity between hours worked and wages, leads us to regard the latter as endogenous, and then to follow an instrumental variables estimation. By contrast, family non-labour income and the children variable will be considered as exogenous. In order to deal with the endogeneity of wages, we have carried out a two-stage estimation. In the first, we estimate two wage equations in which each member's observed wage is regressed in a set of exogenous explanatory variables (experience, educational attainment, occupation, firm size, the type of sector -public or private- and the type of contract -fixed-term or permanent) and, subsequently, we construct an "exogenous" measure of individual wages which are included in the estimation of the system of equation of hours worked. 


\section{III.2. Data}

The data used in this work comes from the panel structure which results from the eight waves of the EHCP (1994-2001)..$^{10}$ The EHCP contains data on individuals in the fifteen pre-enlargement EU countries. It provides abundant information about both the personal and labour characteristics of individuals. This information is homogenous across countries, as the questionnaire is the same and the elaboration process of the survey is co-ordinated by EUROSTAT. We have selected families in which both spouses are between 20 and 64 years old and work as employees in five representative countries (France, Germany, Italy, Spain and UK). Those families lacking the required information have been excluded, resulting in a total sample ranging from 2,342 households in the UK to 4,360 in Italy. Households can stay in the survey all the periods or leave at any period, because of different reasons, as failing to meet the requirements or to provide some information. In this regard, the average period of permanence of a household in the survey varies from 2.4 years in Italy to 4.3 years in the UK.

Table 1 shows the name, and the average value of the main variables used in the analysis. The dependent variables are the number of weekly hours dedicated to paid work, whilst the right hand side variables include hourly wages, household non-labour income, the distribution factor and a variable indicating the number of children under 14 living with their parents. The hourly wage rates, as previously stated, are computed as the annual labour income divided by the number of weekly hours worked times 48 weeks in a year. To control for the endogeneity bias, hourly wage rates are regressed, separately for men and women, on a set of personal and labour characteristics. ${ }^{11}$ The fitted wages are then incorporated to the estimation of the labour supply equations.

The annual household non-labour income includes both non-work private income and total social insurance receipts. ${ }^{12}$ The distribution factor is computed as the ratio between

\footnotetext{
${ }^{10}$ Since income variables refer to the period prior to the interview and the remaining data refer to the current period, the last year is lost for estimation. Thus, the time-series dimension reduces to seven years.

${ }^{11}$ These include experience and squared experience, three dummy variables indicating educational attainment, nine occupational dummies, seven firm size dummies, one dummy for the public sector and one for fixed-term contracts. Results of these estimations are not shown but are available from the authors upon request.

${ }^{12}$ All income variables have been deflated by the annual mean of the Consumer Price Index (CPI) base 1992
} 
the wife's non-labour income and the total non-labour income of the household. As regards the sociodemographic variables, most of these are included in the wage regression and then only one indicating the number of children under 14 living in the household is considered in the estimation of the systems in (5). The intuition for this variable is that as children grow up they do not need attention from their parents. ${ }^{13}$

Although the database provides information about the number of children and the hours devoted by the household to the care of children and/or adult members, there is no information about the time dedicated to housework. As a consequence, we have considered that all the time that an individual does not spend work is devoted to leisure. ${ }^{14}$ In this way, we are forced to ignore the possibility of both household production (see Apps and Rees, 1997; Chiappori, 1997; Aronsson et al., 2001, for discussions on this matter) and public goods consumption (see, e.g., Fong and Zhang, 2001).

(Table 1)

With respect to the dependent variables, a major finding for the five country samples is that husbands dedicate more hours than wives to paid work. Germany is the sample where this difference is the greatest, 44.51 hours/week $(\mathrm{h} / \mathrm{w})$ for husbands as against 36.40 $\mathrm{h} / \mathrm{w}$ for wives, whilst Italy exhibits the lowest, $40.04 \mathrm{~h} / \mathrm{w}$ for husbands as against $34.05 \mathrm{~h} / \mathrm{w}$ for wives. The UK is the country where both spouses spend the most time, as a whole, at paid work, whilst Italy shows the lowest hours per week.

Although hourly wages are expressed in euros, they are not comparable given that purchasing power parity is not the same across countries. This is also true for the family non-labour income. Within each country, male wages are clearly higher than female wages. Spain is the country in which the fraction of the wife's non-labour income (over the household non-labour income) is the highest, at $80 \%$; in France, Germany and Italy it is

and are expressed in euros. The ECHP provides the non-labour income of each of the spouses and the total household income. We have computed household non-labour income as the difference between the total household income minus the total labour income.

${ }^{13}$ Initially, we also introduced the age and squared age into the equation. However, these were always nonsignificant and were eliminated from the final estimation.

${ }^{14}$ Considering only the couples that offer information about hours caring for children or adults severely reduces the samples. 
over $60 \%$, whereas in the UK it is less than $40 \%$. As regards children, the proportion of households with children under 14 varies from $35.2 \%$ in Germany to $51.7 \%$ in France. Similarly, the average number of these children is in the range between 0.81 in France and 0.57 in Germany.

We simultaneously estimate the system of equations, and then perform the test to determine whether or not the collective model is adequate for describing the household labour supply behaviour in the sample countries. This consists of testing the restriction $\frac{\alpha_{3}}{\beta_{3}}=\frac{\alpha_{5}}{\beta_{5}}$, or $\frac{\gamma_{3}}{\delta_{3}}=\frac{\gamma_{7}}{\delta_{7}}$, for the semilog, or the quadratic functional form, respectively.

\section{RESULTS AND POLICY IMPLICATIONS}

For the five sample countries we estimate three models for the two parametric specifications, namely, the pool, the fixed effects and, finally, the random effects. Table 2 shows the LM test that allows us to choose between the pool estimation and the panel estimation, as well as the Hausman test that illustrates how to choose between the fixed and the random effects models. First, the LM test shows that the specification which considers individual effects is preferred to the pool estimation. This requires controlling for the unobserved individual heterogeneity present in the five sample countries. Additionally, the Hausman tests reveal that unobserved individual heterogeneity may be correlated with some of the regressors. In these circumstances, the fixed effects model is preferred over the random effects model and, therefore, the results presented in our tables only correspond to this fixed effects estimation. ${ }^{15}$

The top block of Table 2 shows the estimation for the semilog specification, whereas the bottom block shows those for the quadratic. Direct interpretation of the coefficients on wages and on non-labour income is not straightforward, given the non-

\footnotetext{
${ }^{15}$ Since this is the specification finally chosen, a time-varying distribution factor is selected to avoid the elimination of constant regressors by mean-differencing, as well as the collinearity arising from variables whose differences are constant over time, as, for example, gender differences in age or in experience, which initially were also considered as possible alternative distribution factors.
} 
linearities in the labour supply equations, in such a way that the discussion of these is left until later, when we interpret the elasticities.

However, before that, some general comments can be made. We first observe that collective modelling is non-rejected for both specifications in Italy; it is only rejected for the quadratic formulation in France, Spain and the UK; and rejected in both forms for Germany, although in this case the quadratic form closely approaches non-rejection. This appears in the last row for each block of estimates, where the t-statistic is shown for the restriction tested. ${ }^{16}$ If we are ready to assume that the quadratic form is more appropriate than the semilog, since it allows for a more flexible specification, we can accept that a cooperative modelling of intrahousehold decisions accurately reflects reality in these five EU countries. Thus, in the following we focus only on the results obtained from such specification.

\section{(Table 2)}

Secondly, the sign of the household non-labour income, $y$, the distribution factor, $\mathbf{s}$, and the number of children are clearly informative. Household non-labour income is significant in almost all cases. For wives, the coefficients are always negative, indicating that higher income is related to lower hours supplied. Since those coefficients are positive for husbands, save in the UK, they indicate that women are more sensitive than men to the family non-labour income in the total number of hours of paid-work supplied. This may be interpreted as women dedicating more time to housework and caregiving tasks, a phenomenon commonly found across countries. Only the UK couples show a different pattern of behaviour, perhaps reflecting a stronger desire to work fewer hours -as nonlabour income rises- given that they are the ones who jointly provide more hours of paidwork among the five countries analysed (see Table 1). Secondly, a higher fraction of the non-labour income that corresponds to the wife is associated with a lower number of hours supplied by the wife in all the countries, except in the UK. Again, this result may be

${ }^{16}$ Note that the restrictions tested are if $\frac{\alpha_{3}}{\beta_{3}}=\frac{\alpha_{5}}{\beta_{5}}$ for the semilog specification, or $\frac{\gamma_{3}}{\delta_{3}}=\frac{\gamma_{7}}{\delta_{7}}$, for the quadratic. 
interpreted as women showing more flexibility than men in reducing the number of worked hours. With respect to the UK, note that this is a country in which the average share is considerably lower than in the others, such that a rise in this share may stimulate British women to engage in more hours of work. In Spain and France, a higher share is related to a higher number of hours supplied by the husband, probably indicating some type of substitutability or specialisation within the family. The contrary is the case in the other countries, which may reflect some form of income effect, by which a higher value in the share of wives non-labour income induces less work outside the home by the husbands. Thirdly, when there are children under 14 in the household, the number of hours supplied by the wife is lower, whereas the impact on the husband's hours of work is non-significant in Italy, Germany and the UK, but clearly positive in Spain and France. In fact, in both these latter, the husband's labour supply increases, confirming the existence of a specialisation within the household, see Lundberg and Rose (2000).

As mentioned earlier, in order to analyse the effects of both wages and non-labour income on the hours of work supplied, it is appropriate to compute the elasticities, evaluated at the sample means, for each of the spouses. We first indicate that our values are in line with those obtained in the recent literature (Vermeulen, 2005). Since the collective model is generally non-rejected under the quadratic specification, we refer only to the results shown in the second column of Table 3 for each of the countries. A first result is that a rise in the wage of wives has no (or a reduced) effect on the hours supplied in paid-work by their husbands, labelled in Table 3 as $\mathrm{Eh}_{\mathrm{h}} \mathrm{W}_{\mathrm{w}}$, whereas it has a great influence on the hours supplied by the wives themselves, $\mathrm{Eh}_{\mathrm{w}} \mathrm{W}_{\mathrm{w}}$. In Germany and the $\mathrm{UK}$, such influence is positive, and in France and Italy, negative. It can then be deduced that German and British wives are in the upward sloping section of their labour supply functions, whereas French and Italian wives are in the section in which the curves are backward bending. As regards a rise in the husband's wages, it has no impact on the hours supplied by their wives, except a strongly negative influence in the case of Spain, see the row headed by $\mathrm{Eh}_{\mathrm{w}} \mathrm{w}_{\mathrm{h}}$. In Spain, a rise in the husband's wages reduces the hours supplied by the husband, as it does in Italy, whereas it increases in the other countries -though, not in a significant way in France (see $\mathrm{Eh}_{\mathrm{h}} \mathrm{W}_{\mathrm{h}}$ ). Similarly, as in the case of wives, Spanish and Italian husbands are in the 
downward sloping section of their labour supply curves, whereas German and British husbands are in the upward sloping section.

Taken together, it seems that German and British couples react positively to rises in their wages, which may indicate a relatively lower valuation for leisure (or domestic work), such that a substitution effect dominates. By contrast, in the three Mediterranean countries, when the price of leisure rises, this is relatively more highly valued, such that the income effect dominates. Overall, these results may be interpreted as a distinct view of paid-work activities from the Northern perspective compared to the view from the Mediterranean.

When the rise in total income is only due to a higher availability of non-labour sources, a first clear result is that, unequivocally, wives always supply fewer hours of paid work, these results are shown in the row $E h_{w} \mathrm{y}$. In the case of husbands the evidence is mixed: French and Spanish men tend to supply more hours, the contrary being observed in the other three countries $\left(\mathrm{Eh}_{\mathrm{h}} \mathrm{y}\right)$. Again, this shows that specialisation may be driving family behaviour in France and Spain, such that men are more willing to engage in paid work, whereas wives dedicate more time to other activities (more than likely, housework or caregiving). In the other countries, higher non-labour income leads to fewer hours of work supplied by the couple, showing a clear preference for those alternative activities.

(Table 3)

From these results some policy implications can immediately be derived. Our estimates indicate that female labour supply is strongly influenced by both the amount of family income and the presence of children in the household. In order to make women's decisions on labour supply less dependent on these "family" factors, more equality between genders must be the target in the process of policy design. This may require two lines of approach. First, a general campaign by which female work should be valued, not only as a source of income, but also as a way of self-satisfaction and fulfillment. In this context, spouses should be committed to the sharing of housework, including childcare, in such a way that the labour supply of wives becomes less dependent on those "family" factors. ${ }^{17}$

\footnotetext{
${ }^{17}$ A recent study by Couprie (2003) shows that today, in the UK, the younger generation does not appear to
} 
Second, the implementation of some measures aiming to make paid-work and housework compatible. Specifically, flexible time schedules that allow childcare during working time, and the establishment and growth of kindergardens at the work place with flexible timetables.

\section{SUMMARY AND CONCLUSIONS}

The aim of this paper has been to analyse the intra-family distribution of paid-work time in five representative EU countries (France, Germany, Italy, Spain and the UK). To that end, we have formulated two labour-supply specifications, semilogarithmic and quadratic, which have been estimated for the five national samples by using the European Community Household Panel-ECHP (1994-2001).

After proving that, in all cases, fixed effects is the preferred estimation method, we have observed that the collective model is non-rejected for the quadratic specifications in all sample countries, save Germany. With respect to estimations, we can draw the following conclusions. First, as a whole, working wives in Spain, the UK and Germany, represent the portion of the labour supply in which a wage increase leads to the supply of more hours of work. Conversely, in Italy and in France, wage increases lead women to devote more time to activities different from paid-work. Secondly, in all countries non-labour income is a significant variable in the amount of work supplied by wives: when this increases, labour supply decreases. Thirdly, the share of the wife's non-labour income over the household non-labour income is a relevant variable in deciding the amount of working hours supplied by each spouse. It has a negative effect in the case of wives, and a positive one in the case of husbands (except in the UK, where this share is considerably lower than in the rest of the sample countries). Fourthly, children under 14, who require more time, have a negative effect on the labour supply of wives, but not on that of husbands. Overall, it seems that, with some minor differences across countries, wives' labour supply is more affected by children and the proportion of non-labour income than that of men. Similarly, the response

have experienced a change of attitude regarding gender equality in the family. 
in hours worked by women is clearly dependent on own hourly wage, household non-labour income, the factors that contribute to the household non-labour income and the number of children. However, there is no clear evidence across countries of the influence of her spouse's wage on the number of paid-work hours.

In short, we have noted that there is homogeneous performance across countries with respect to the behaviour of wives, with their labour supply being more affected than that of husbands by child care and non-labour income. Furthermore, the direction of the influence of own wages, household non-labour income, the proportion of non-labour income coming from wives, and the number of children, is the same across countries. As regards husbands, however, the results are quite different, the only common feature being the reduced influence of both the number of children and the household non-labour income in deciding the number of hours devoted to paid-work.

\section{ACKNOWLEDGEMENTS}

This paper was partially written while José Alberto Molina was Visiting Fellow at the Department of Economics of the University of Warwick (UK), to which he would like to express his thanks for the hospitality and facilities provided. An earlier version of this paper has been presented at the $31^{\text {st }}$ Spanish Economic Analysis Meeting-2006 (Oviedo, Spain), with all the comments made by the participants being highly appreciated. Finally, the authors also thanks for the financial support provided by the Spanish Government (Grant SEC2005-06522), as well as by the Fundación BBVA. The usual disclaimer applies 


\section{REFERENCES}

Apps, P. and Rees, R. (1997) Collective labor supply and household production, Journal of Political Economy, 105, 178-190.

Aronsson, T., Daunfeldt, S-O. and Wikström, M. (2001) Estimating intrahousehold allocation in a collective model with household production, Journal of Population Economics, 14, 569-584.

Barmby, T. and Smith, N. (2001) Household labour supply in Britain and Denmark: some interpretations using a model of Pareto optimal behaviour, Applied Economics, 33, 11091116.

Becker, G.S. (1974a) A theory of marriage: part II, Journal of Political Economy, 82, S11S26.

Becker, G.S. (1974b) A theory of social interactions, Journal of Political Economy, 82, 1063-1093.

Bloemen, H.G. (2004) An empirical model of collective household labour supply with nonparticipation, Research Memorandum ALERT 2004-2, Free University, Amsterdam.

Blundell, R., Chiappori, P.A., Magnac, T. and Meghir, C. (2002) Collective labor supply: heterogeneity and nonparticipation, Mimeo, Institute for Fiscal Studies, London.

Browning, M. (2000) The saving behaviour of a two-person household, Scandinavian Journal of Economics, 102, 235-51.

Browning, M., Bourguignon, F., Chiappori, P-A. and Lechene, V. (1994) Income and outcomes: a structural model of intrahousehold allocation, Journal of Political Economy, 102, 1067-1096.

Browning, M. and Chiappori, P-A. (1998) Efficient intra-household allocations: a general characterization and empirical tests, Econometrica, 66, 1241-1278.

Chiappori, P-A. (1988) Rational household labor supply, Econometrica, 56, 63-89.

Chiappori, P-A. (1992) Collective labor supply and welfare, Journal of Political Economy, 100, 437-467.

Chiappori, P-A. (1997) Introducing household production in collective models of labor supply, Journal of Political Economy, 105, 191-209. 
Chiappori, P-A., Fortin, B. and Lacroix, G. (2002) Marriage market, divorce legislation and household labor supply, Journal of Political Economy, 110, 37-72.

Clark, A., Couprie, H. and Sofer, C. (2002) Household negotiation and labor supply: evidence from the BHPS, Institut d'economie publique (IDEP), France in its series IDEP Working Papers 2004 with number 0201, Marseille.

Connelly, R. and Kimmel, J. (2003) Marital status and full-time/part-time work status in child care choices, Applied Economics, 35, 761-777.

Couprie, H. (2003) Time allocation within the family: welfare implications of life in a couple, Document de Travail, DT-GREQAM 02A23, Marseille.

Crespo, L. (2005) Estimation and testing of household labour supply models: evidence from Spain, Working Papers, Serie AD 2005-03, Instituto Valenciano de Investigaciones Económicas, S.A. (IVIE).

Doiron, D. and Guyonne, K. (2005) Demands for child care and household labour supply in Australia, Economic Record, 81, 215-236.

Donni, O. (2003) Collective household labor supply: non-participation and income taxation, Journal of Public Economics, 87, 1179-1198.

Fernández-Val, I. (2003) Household labor supply: evidence for Spain, Investigaciones Economicas, Fundación SEPI, 27, 239-275.

Flood, L., Hansen, J. and Wahlberg, R. (2004) Household labor supply and welfare participation in Sweden, Journal of Human Resources, 29, 1008-1032.

Fong, Y-F. and Zhang, J. (2001) The identification of unobservable independent and spousal leisure, Journal of Political Economy, 109, 191-202.

Fortin, B. and Lacroix, G. (1997) A test of the unitary and collective models of household labour supply, The Economic Journal, 107, 933-955.

García, I. and Molina, J.A. (1998) Household labour supply with rationing in Spain, Applied Economics, 30, 1557-1570.

Iyigun, M. and Walsh, R.P. (2007) Endogenous gender power, household labor supply and the demographich transition, Journal of Development Economics, 82, 138-155.

Kawaguchi, A. (1994) Testing neoclassical models of household labour supply, Applied Economics, 26, 9-19. 
Konrad, K. and Lommerud, K. (1995) Family policy with non-cooperative families, Scandinavian Journal of Economics, 97, 581-601.

Kooreman, P. and Kapteyn, A. (1987) A disaggregated analysis of the allocation of time within the household, Journal of Political Economy, 95, 223-249.

Kooreman, P. and Kapteyn, A. (1990) On the empirical implementation of some game theoretic models of household labor supply, Journal of Human Resources, 25, 584-598.

Kyriazidou, E. (1997) Estimation of a panel data sample selection model, Econometrica, 65, 1335-1364.

Manser, M. and Brown, M. (1980) Marriage and household decision-making: A bargaining analysis, International Economic Review, 21, 31-44.

McElroy, M. (1990) The empirical content of Nash bargained household behaviour, Journal of Human Resources, 25, 559-583.

McElroy, M. and Horney, M. (1981) Nash-bargained household decisions: toward a generalization of the theory of demand, International Economic Review, 23, 333-349.

Powel, L.M. (1998) Part-time versus full-time work and child care costs: evidence for married mothers, Applied Economics, 30, 503-511.

Pradhan, M. and Van Soest, A. (1997) Household labor supply in urban areas of Bolivia, Review of Economics and Statistics, 79, 300-310.

Samuelson, P. (1956) Social indifference curves, The Quarterly Journal of Economics, 70, $1-22$.

Schultz, T.P. (1990) Testing the neoclassical model of family labor supply, Journal of Human Resources, 25, 599-634.

Seaton, J.S. (1997) Neoclassical and collective rationality in household labour supply, Applied Economics Letters, 4, 529-533.

Tiefenthaler, J. (1999) The sectorial labor supply of married couples in Brazil: testing the unitary model of household behaviour, Journal of Population Economics, 12, 591-606.

Thomas, D. (1990) Intra-household resource allocation: an inferential approach, Journal of Human Resources, 25, 635-664.

Vermeulen, F. (2002) Collective household models: principles and main results, Journal of Economic Surveys, 16, 533-564. 
Vermeulen, F. (2005) And the winner is... An empirical evaluation of unitary and collective labour supply models, Empirical Economics, 30, 711-734.

Weiss, Y., Willis, R.J. (1985) Children as collective goods and divorce settlements, Journal of Labour Economics, 19, 268-292.

Wooldridge, J.M. (2002) Econometric analysis of cross section and panel data, MIT Press.

Yamada, T. and Yamada T. (1987) Labor employment of married women in Japan: parttime work vs. full-time work, Eastern Economic Journal, 13, 41-48. 
Table 1. Descriptive analysis. Pooled data 1994-2001

\begin{tabular}{lccccc}
\hline & France & Germany & Italy & Spain & UK \\
\hline Hours of work $_{\mathrm{h}}{ }^{\mathrm{a}}$ & 43.06 & 44.51 & 40.04 & 42.83 & 45.66 \\
Hours of work $_{\mathrm{w}}{ }^{\mathrm{a}}$ & 35.69 & 36.40 & 34.05 & 36.70 & 38.43 \\
Wage per hour $_{\mathrm{h}}{ }_{\mathrm{b}}$ & 9.02 & 8.08 & 7.39 & 6.08 & 8.30 \\
Wage per hour $_{\mathrm{w}}{ }^{\mathrm{b}}$ & 6.68 & 6.29 & 6.29 & 4.60 & 6.87 \\
$\begin{array}{l}\text { Family nonlabor } \\
\text { income, y }\end{array}$ & $2,639.01$ & $2,217.37$ & $2,238.38$ & $1,307.18$ & $2,041.87$ \\
\% nonlabor wife & 0.69 & 0.68 & 0.62 & 0.80 & 0.36 \\
income, $\mathrm{s}$ & & & & & \\
Children $(<14)$ & 0.81 & 0.57 & 0.70 & 0.72 & 0.62 \\
\hline
\end{tabular}

Notes: ${ }^{\mathrm{a}}$ Weekly hours. ${ }^{\mathrm{b}}$ Hourly wages expressed in euros. ${ }^{\mathrm{c}}$ Expressed in euros. 
Table 2. Parameter and test results. Fixed effects model

\begin{tabular}{|c|c|c|c|c|c|c|c|c|c|c|}
\hline & \multicolumn{2}{|c|}{ France } & \multicolumn{2}{|c|}{ Germany } & \multicolumn{2}{|c|}{ Italy } & \multicolumn{2}{|c|}{ Spain } & \multicolumn{2}{|c|}{ UK } \\
\hline & $\mathrm{W}$ & $\mathrm{H}$ & $\mathrm{W}$ & $\mathrm{H}$ & $\mathrm{W}$ & $\mathrm{H}$ & W & $\mathrm{H}$ & $\mathrm{W}$ & $\mathrm{H}$ \\
\hline \multicolumn{11}{|l|}{ Semilog } \\
\hline $\log w_{w}$ & $\begin{array}{l}-0.025 \\
(-0.44)\end{array}$ & $\begin{array}{l}0.358 \\
(3.62)\end{array}$ & $\begin{array}{c}0.800 \\
(12.54)\end{array}$ & $\begin{array}{l}-0.341 \\
(-3.06)\end{array}$ & $\begin{array}{l}0.014 \\
(0.10)\end{array}$ & $\begin{array}{l}0.209 \\
(1.07)\end{array}$ & $\begin{array}{l}-0.177 \\
(-3.73)\end{array}$ & $\begin{array}{l}0.576 \\
(7.92)\end{array}$ & $\begin{array}{c}1.901 \\
(16.39)\end{array}$ & $\begin{array}{l}0.913 \\
(4.05)\end{array}$ \\
\hline $\log _{\mathrm{h}}$ & $\begin{array}{l}0.046 \\
(0.56)\end{array}$ & $\begin{array}{l}0.056 \\
(0.74)\end{array}$ & $\begin{array}{l}-0.613 \\
(-7.37)\end{array}$ & $\begin{array}{l}0.637 \\
(7.68)\end{array}$ & $\begin{array}{l}0.446 \\
(2.00)\end{array}$ & $\begin{array}{l}-0.046 \\
(-0.24)\end{array}$ & $\begin{array}{l}-0.683 \\
(-8.95)\end{array}$ & $\begin{array}{l}-0.380 \\
(-7.63)\end{array}$ & $\begin{array}{l}-0.609 \\
(-4.25)\end{array}$ & $\begin{array}{l}0.678 \\
(3.99)\end{array}$ \\
\hline $\log w_{h} \log w_{w}$ & $\begin{array}{l}-0.071 \\
(-1.90)\end{array}$ & $\begin{array}{l}-0.072 \\
(-1.90)\end{array}$ & $\begin{array}{l}0.220 \\
(5.99)\end{array}$ & $\begin{array}{l}0.220 \\
(5.99)\end{array}$ & $\begin{array}{l}-0.074 \\
(-0.77)\end{array}$ & $\begin{array}{l}-0.074 \\
(-0.77)\end{array}$ & $\begin{array}{l}0.084 \\
(6.46)\end{array}$ & $\begin{array}{l}0.084 \\
(6.46)\end{array}$ & $\begin{array}{l}0.644 \\
(7.83)\end{array}$ & $\begin{array}{l}0.644 \\
(7.83)\end{array}$ \\
\hline $\mathrm{y}$ & $\begin{array}{l}-0.825 \\
(-4.96)\end{array}$ & $\begin{array}{l}1.027 \\
(6.04)\end{array}$ & $\begin{array}{l}-0.897 \\
(-2.02)\end{array}$ & $\begin{array}{l}-1.708 \\
(-4.00)\end{array}$ & $\begin{array}{l}-1.223 \\
(-2.45)\end{array}$ & $\begin{array}{l}-1.054 \\
(-2.11)\end{array}$ & $\begin{array}{l}-0.097 \\
(-5.27)\end{array}$ & $\begin{array}{l}0.028 \\
(1.56)\end{array}$ & $\begin{array}{l}-5.386 \\
(-3.23)\end{array}$ & $\begin{array}{l}-6.224 \\
(-3.8)\end{array}$ \\
\hline s & $\begin{array}{l}-2.444 \\
(-11.42)\end{array}$ & $\begin{array}{c}2.944 \\
(14.01)\end{array}$ & $\begin{array}{l}-1.724 \\
(-5.21)\end{array}$ & $\begin{array}{l}-0.861 \\
(-2.81)\end{array}$ & $\begin{array}{l}-0.826 \\
(-1.99)\end{array}$ & $\begin{array}{l}-0.375 \\
(-0.91)\end{array}$ & $\begin{array}{l}-4.315 \\
(-12.13)\end{array}$ & $\begin{array}{l}2.131 \\
(6.30)\end{array}$ & $\begin{array}{l}1.734 \\
(5.11)\end{array}$ & $\begin{array}{l}-0.867 \\
(-2.6)\end{array}$ \\
\hline $\begin{array}{l}\text { Children } \\
(<14)\end{array}$ & $\begin{array}{l}-1.312 \\
(-12.98)\end{array}$ & $\begin{array}{l}0.645 \\
(6.72)\end{array}$ & $\begin{array}{l}-1.551 \\
(-10.75)\end{array}$ & $\begin{array}{l}0.133 \\
(0.98)\end{array}$ & $\begin{array}{l}-1.101 \\
(-3.58)\end{array}$ & $\begin{array}{l}-0.118 \\
(-0.39)\end{array}$ & $\begin{array}{l}-1.311 \\
(-7.37)\end{array}$ & $\begin{array}{l}0.314 \\
(1.96)\end{array}$ & $\begin{array}{l}-2.728 \\
(-16.86)\end{array}$ & $\begin{array}{l}0.142 \\
(0.96)\end{array}$ \\
\hline $\mathrm{LM}$ & \multicolumn{2}{|c|}{$\begin{array}{l}18393 \\
(0.000)\end{array}$} & \multicolumn{2}{|c|}{$\begin{array}{c}23729 \\
(0.0000)\end{array}$} & \multicolumn{2}{|c|}{4199} & \multicolumn{2}{|c|}{$\begin{array}{c}3766 \\
(0.0000)\end{array}$} & \multicolumn{2}{|c|}{$\begin{array}{l}16808 \\
(0.0000)\end{array}$} \\
\hline Hausman & \multicolumn{2}{|c|}{$\begin{array}{c}97.78 \\
(0.000)\end{array}$} & \multicolumn{2}{|c|}{$\begin{array}{c}508.63 \\
(0.0000)\end{array}$} & \multicolumn{2}{|c|}{$\begin{array}{c}47.38 \\
(0.0000)\end{array}$} & \multicolumn{2}{|c|}{$\begin{array}{c}215.23 \\
(0.0000)\end{array}$} & \multicolumn{2}{|c|}{$\begin{array}{c}272.23 \\
(0.0000)\end{array}$} \\
\hline $\begin{array}{l}\text { t-ratio } \\
\text { quadratic }\end{array}$ & \multicolumn{2}{|c|}{15.54} & \multicolumn{2}{|c|}{3.70} & \multicolumn{2}{|c|}{-0.45} & \multicolumn{2}{|c|}{7.25} & \multicolumn{2}{|c|}{3.50} \\
\hline $\mathrm{w}_{\mathrm{w}}^{2}$ & $\begin{array}{c}-0.0002 \\
(-2.95)\end{array}$ & $\begin{array}{c}-0.0002 \\
(-2.38)\end{array}$ & $\begin{array}{l}-0.017 \\
(-9.64)\end{array}$ & $\begin{array}{c}-0.0003 \\
(-0.16)\end{array}$ & $\begin{array}{l}-0.006 \\
(-1.54)\end{array}$ & $\begin{array}{l}-0.006 \\
(-1.54)\end{array}$ & $\begin{array}{c}1.9410^{-6} \\
(-6.06)\end{array}$ & $\begin{array}{c}9.3210^{-7} \\
(2.74)\end{array}$ & $\begin{array}{c}-0.037 \\
(-13.10)\end{array}$ & $\begin{array}{c}-0.018 \\
(- \\
3.12)\end{array}$ \\
\hline$w_{h}^{2}$ & $\begin{array}{c}0.0001 \\
(0.43)\end{array}$ & $\begin{array}{c}0.0002 \\
(1.04)\end{array}$ & $\begin{array}{l}0.005 \\
(2.28)\end{array}$ & $\begin{array}{l}0.005 \\
(3.56)\end{array}$ & $\begin{array}{l}0.001 \\
(0.32)\end{array}$ & $\begin{array}{l}-0.005 \\
(-1.33)\end{array}$ & $\begin{array}{c}1.2010^{-7} \\
(0.57)\end{array}$ & $\begin{array}{c}1.2610^{-6} \\
(7.45)\end{array}$ & $\begin{array}{l}-0.004 \\
(-1.14)\end{array}$ & $\begin{array}{l}0.004 \\
(0.25)\end{array}$ \\
\hline $\mathrm{w}_{\mathrm{w}} \mathrm{w}_{\mathrm{h}}$ & $\begin{array}{c}-0.0008 \\
(-0.43)\end{array}$ & $\begin{array}{c}-0.0001 \\
(-0.55)\end{array}$ & $\begin{array}{l}0.002 \\
(1.38)\end{array}$ & $\begin{array}{l}-0.095 \\
(-2.38)\end{array}$ & $\begin{array}{l}-0.005 \\
(-1.38)\end{array}$ & $\begin{array}{l}-0.0005 \\
(-0.15)\end{array}$ & $\begin{array}{c}1.7910^{-6} \\
(6.22)\end{array}$ & $\begin{array}{c}-1.6410^{-6} \\
(-5.86)\end{array}$ & $\begin{array}{l}-0.005 \\
(-1.48)\end{array}$ & $\begin{array}{l}0.001 \\
(0.30)\end{array}$ \\
\hline $\mathrm{w}_{\mathrm{w}}$ & $\begin{array}{l}-0.001 \\
(-0.14)\end{array}$ & $\begin{array}{l}0.041 \\
(4.26)\end{array}$ & $\begin{array}{c}0.530 \\
(13.54)\end{array}$ & $\begin{array}{l}0.217 \\
(4.93)\end{array}$ & $\begin{array}{l}0.123 \\
(1.53)\end{array}$ & $\begin{array}{l}0.046 \\
(0.57)\end{array}$ & $\begin{array}{l}0.001 \\
(1.92)\end{array}$ & $\begin{array}{c}0.0005 \\
(0.88)\end{array}$ & $\begin{array}{c}1.392 \\
(20.44)\end{array}$ & $\begin{array}{l}0.261 \\
(2.95)\end{array}$ \\
\hline $\mathrm{w}_{\mathrm{h}}$ & $\begin{array}{l}-0.006 \\
(-0.34)\end{array}$ & $\begin{array}{l}-0.004 \\
(-0.28)\end{array}$ & $\begin{array}{l}-0.172 \\
(-3.87)\end{array}$ & $\begin{array}{l}-1.785 \\
(-4.18)\end{array}$ & $\begin{array}{l}0.087 \\
(1.09)\end{array}$ & $\begin{array}{l}-1.071 \\
(-2.14)\end{array}$ & $\begin{array}{l}-0.004 \\
(-6.48)\end{array}$ & $\begin{array}{l}-0.004 \\
(-8.46)\end{array}$ & $\begin{array}{l}0.024 \\
(0.34)\end{array}$ & $\begin{array}{l}0.084 \\
(1.70)\end{array}$ \\
\hline $\mathrm{y}$ & $\begin{array}{l}-0.786 \\
(-4.72)\end{array}$ & $\begin{array}{l}0.990 \\
(5.81)\end{array}$ & $\begin{array}{l}-0.895 \\
(-2.01)\end{array}$ & $\begin{array}{l}0.140 \\
(1.03)\end{array}$ & $\begin{array}{l}-1.241 \\
(-2.49)\end{array}$ & $\begin{array}{l}0.120 \\
(1.54)\end{array}$ & $\begin{array}{l}-0.094 \\
(-5.12)\end{array}$ & $\begin{array}{l}0.032 \\
(1.73)\end{array}$ & $\begin{array}{l}-4.737 \\
(-2.84)\end{array}$ & $\begin{array}{l}-6.525 \\
(-4.0)\end{array}$ \\
\hline s & $\begin{array}{c}-2.390 \\
(-11.10)\end{array}$ & $\begin{array}{c}2.867 \\
(13.57)\end{array}$ & $\begin{array}{l}-2.457 \\
(-5.44)\end{array}$ & $\begin{array}{l}-0.817 \\
(2.66)\end{array}$ & $\begin{array}{l}-0.827 \\
(-2.00)\end{array}$ & $\begin{array}{l}-0.413 \\
(-1.00)\end{array}$ & $\begin{array}{c}-4.285 \\
(-11.76)\end{array}$ & $\begin{array}{l}2.315 \\
(6.75)\end{array}$ & $\begin{array}{l}1.552 \\
(4.56)\end{array}$ & $\begin{array}{l}-0.870 \\
(-2.6)\end{array}$ \\
\hline $\begin{array}{l}\text { Children } \\
(<14)\end{array}$ & $\begin{array}{c}-1.927 \\
(-14.50)\end{array}$ & $\begin{array}{l}0.638 \\
(6.62)\end{array}$ & $\begin{array}{c}-1.523 \\
(-10.54)\end{array}$ & $\begin{array}{l}0.140 \\
(1.03)\end{array}$ & $\begin{array}{l}-1.088 \\
(-3.54)\end{array}$ & $\begin{array}{l}-0.148 \\
(-0.49)\end{array}$ & $\begin{array}{l}-1.668 \\
(-9.21)\end{array}$ & $\begin{array}{l}0.344 \\
(2.12)\end{array}$ & $\begin{array}{c}-2.666 \\
(-16.43)\end{array}$ & $\begin{array}{l}0.113 \\
(0.76)\end{array}$ \\
\hline $\mathrm{N}$ & 115 & & 127 & & & 465 & & 83 & 100 & \\
\hline LM & $\begin{array}{r}95 \\
(0.0\end{array}$ & $\begin{array}{l}91 \\
00)\end{array}$ & $\begin{array}{l}234 \\
(0.0\end{array}$ & $\begin{array}{c}61 \\
00)\end{array}$ & & $\begin{array}{l}64 \\
00)\end{array}$ & $\begin{array}{r}3 \\
(0.8\end{array}$ & $\begin{array}{l}65 \\
000)\end{array}$ & $\begin{array}{l}164 \\
(0.00\end{array}$ & \\
\hline Hausman & $\begin{array}{l}382 \\
(0.0\end{array}$ & $\begin{array}{l}.43 \\
00)\end{array}$ & $\begin{array}{l}542 \\
(0.0\end{array}$ & $\begin{array}{l}.72 \\
00)\end{array}$ & & .16 & & $\begin{array}{l}00 \\
000)\end{array}$ & $\begin{array}{l}223 . \\
(0.00\end{array}$ & \\
\hline t-ratio & 0.6 & & 2.6 & & & 12 & & 70 & -0.1 & \\
\hline
\end{tabular}


Table 3. Elasticities

\begin{tabular}{cccccccccccc}
\hline & \multicolumn{2}{c}{ France } & \multicolumn{2}{c}{ Germany } & \multicolumn{2}{c}{ Italy } & \multicolumn{2}{c}{ Spain } & \multicolumn{3}{c}{ UK } \\
\cline { 2 - 11 } & Sem & Quad & Sem & Quad & Sem & Quad & Sem & Quad & Sem & Quad \\
\cline { 2 - 11 } $\mathrm{Eh}_{\mathrm{w}} \mathrm{W}_{\mathrm{w}}$ & -0.009 & -0.033 & 0.039 & 0.048 & -0.005 & -0.032 & 0.011 & 0.001 & 0.075 & 0.119 \\
& $(-2.22)$ & $(-2.88)$ & $(16.21)$ & $(8.89)$ & $(-0.81)$ & $(-2.25)$ & $(5.31)$ & $(0.17)$ & $(22.53)$ & $(22.9)$ \\
$\mathrm{Eh}_{\mathrm{h}} \mathrm{w}_{\mathrm{h}}$ & -0.005 & 0.026 & 0.027 & 0.024 & -0.006 & -0.041 & 0.004 & -0.065 & 0.036 & 0.012 \\
& $(-2.07)$ & $(1.35)$ & $(18.52)$ & $(2.77)$ & $(-1.53)$ & $(-2.47)$ & $(2.81)$ & $(-11.41)$ & $(14.07)$ & $(2.88)$ \\
$\mathrm{Eh}_{\mathrm{w}} \mathrm{W}_{\mathrm{h}}$ & -0.006 & 0.005 & -0.002 & -0.001 & 0.008 & 0.029 & -0.003 & -0.055 & 0.010 & -0.007 \\
& $(-1.90)$ & $(0.20)$ & $(-0.77)$ & $(-0.11)$ & $(1.47)$ & $(1.51)$ & $(-2.36)$ & $(-7.73)$ & $(2.82)$ & $(-1.49)$ \\
$\mathrm{Eh}_{\mathrm{h}} \mathrm{W}_{\mathrm{w}}$ & 0.002 & 0.022 & 0.006 & -0.008 & 0.0003 & -0.010 & 0.0027 & 0.005 & 0.044 & 0.010 \\
& $(0.37)$ & $(2.34)$ & $(1.87)$ & $(-1.75)$ & $(0.04)$ & $(-0.83)$ & $(10.94)$ & $(1.04)$ & $(7.89)$ & $(2.01)$ \\
$\mathrm{Eh}_{\mathrm{w}} \mathrm{y}$ & -0.008 & -0.007 & -0.002 & -0.002 & -0.001 & -0.001 & -0.006 & -0.006 & -0.004 & -0.003 \\
& $(-4.96)$ & $(-4.72)$ & $(-2.02)$ & $(-2.01)$ & $(-2.45)$ & $(-2.49)$ & $(-5.27)$ & $(-5.12)$ & $(-3.23)$ & $(-2.84)$ \\
$\mathrm{Eh}_{\mathrm{h}} \mathrm{y}$ & 0.008 & 0.008 & -0.003 & -0.003 & -0.0009 & -0.0009 & 0.001 & 0.002 & -0.004 & -0.003 \\
& $(6.04)$ & $(5.81)$ & $(-4.00)$ & $(-4.18)$ & $(-2.11)$ & $(-2.14)$ & $(1.56)$ & $(1.73)$ & $(-3.82)$ & $(-4.00)$ \\
\hline
\end{tabular}

Note: t-statistic within parentheses

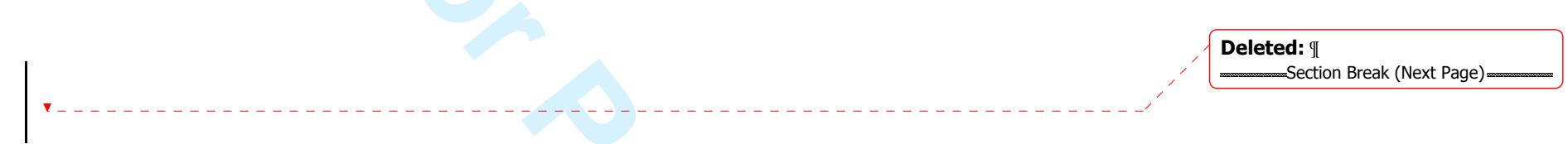

